\title{
Velho Cenário*.
}

\author{
Oliveira Ribeiro Neto \\ Da Academia Paulista de Letras
}

No Largo de São Francisco, pela Rua da Freira, na Rua da Cruz Preta ou na Rua Direita do Imperador, na Rua de São Bento ou no quente e aceso Beco das Quitandeiras, dizem até que no Anhangabaú, ou na Subida da Memória, ou no Largo dos Curros, ecoa o sino do torreão de taipa seiscentista, chamando os moços, que é hora de acordar. Mas cadê coragem para se seguer da rede, pra levantar do catre de colchão de palha sonhando ainda com as graças da Ritinha ou da Eufrásia, e os encantos mais recônditos das Sinhás brejeiras dos sobradões austeros! $\mathrm{E}$ o sino repica em faiscas no ar dourado, ou a tremer de frio, embuçado na garoa. Em passo medido, atravessando a Praça, abotoando a sobrecasaca de abas largas Mestre José Bonifácio, o Moço, vem chegando, saudando a uns e outros em cumprimentos vários, a compor, romântico e silente mais na alma que na voz: Meu Testamento. "Vem cá. Traze a caixinha de costura, e em vez de agulha, tira o teu rosário.

O caso é grave, sério. Pode causar-te riso. Tu vais servir-me agora de notário.

"Em nome da Santíssima Trindade, livre o juízo e são o entendimento,

* Poesia declamada pelo autor na solenidade de encerramento do sesquicentenário de fundação dos Cursos Jurídicos no Brasil, a 11 de agosto de 1977, no salão nobre desta Faculdade. 
sentado em teu banquinho, inda a teus pés sonhando, eu dito. Escreve tu: Meu Testamento."

$\mathrm{O}$ sino toca. $\mathrm{E}$ aos portões estreitos

do velho paredão da Faculdade, os moços vão chegando, como um bando matutino de sabiás e gralhas faladeiras, enquanto São Francisco, adolescente como eles, do altar barroco os abençoa nos roteiros de glória e caminhos sonhados, de justiça, de poesia e liberdade.

Nas tardes calmas, nas noites estreladas, bate o sino chamando para as aulas ou para as cerimônias da cidade, - e da Pátria também, pois São Francisco não se esquece da pátria bem amada.

Depois, São Paulo cresce e se agiganta, corre o tempo em pégasos fogosos ou em asnos pachorrentos e bisonhos, mas há cento e cincoenta anos estas cenas, sem os sinos, com outros mestres e outros moços, com outras modas e gírias, se repetem nas mesmas ânsias e nos mesmos sonhos.

Olhai, vós que me ouvis e quereis ver. No velho casarão de taipas rústicas que o cimento trocou nos seus arroubos, a mesma vida corre pelas salas e ergue as mentes dos mestres e dos moços. Há um cadinho que ferve em cada canto. A liberdade fulge, a mocidade vibra, os mestres formam turmas de outros mestres que ensinam ao Brasil a ter no sangue a semente do orgulho e da verdade. Refulge o Pátio, é um arsenal a liça. Sobre o trono de luzes e de hósanas, erguendo a espada que a mantém serena na sua glória que não mede o risco, sobre a Faculdade sempre renovada, num halo de ciência e segurança, derrama as suas bênçãos e o seu credo a mão iluminada da Justiça. Olhai, isto é São Paulo! Olhai, é São Francisco! 